\title{
Interpreting Fiscal Risk for Lack of Bank Indonesia's Capital
}

\author{
Yuli Indrawati \\ Administrative Law Department, Universitas Indonesia, Indonesia. \\ Corresponding author:yulifhui@gmail.com
}

\begin{tabular}{l} 
ARTICLE INFO \\
\hline Keywords: \\
Bank Indonesia capital; \\
fiscal risk; monetary \\
stability; role of the state \\
How to cite: \\
Indrawati, Y. (2021). \\
Interpreting Fiscal Risk \\
for Lack of Bank \\
Indonesia's Capital. \\
Jurnal Media Hukum, \\
28(1), 90-101 \\
Article History: \\
Received: 30-04-2020 \\
Reviewed: 29-12-2020 \\
Revised: 16-04-2021 \\
Accepted: 30-06-2021
\end{tabular}

\begin{abstract}
The research is focused on determining the government's obligation to meet the shortage of capital of Bank Indonesia (BI), as the central bank, in the National State Budget (APBN). The research analyzes the basis of the government's obligation to meet BI's lack of capital and a mechanism for fulfilling the government's obligations to cover $B I$ deficiencies in line with the objectives of the APBN. This study uses a normative legal research method with a statute, interdisciplinary, and analytical approach. The result shows that the government's obligation to suffice BI's capital is intended to maintain BI's sustainability so that BI can continue to carry out its responsibilities and obligations to maintain monetary stability. Monetary stability has implications for economic stability and increases in people's welfare. In addition, the fulfilment of government obligations is contingent, limited and final. This obligation will only be born if BI is no longer able to overcome the lack of capital. The cause of the lack of capital is beyond BI's control, as evidenced by the results of an examination by the Supreme Audit Agency and requires the approval of the House of Representatives.
\end{abstract}

DOI: $\underline{\text { https://doi.org/10.18196/jmh.v28i1.8712 }}$

Copyright $@ 2021$ JURNAL MEDIA HUKUM. All rights reserved.

\section{Introduction}

In the current global era, economic conditions are heavily influenced by the dynamics in the financial sector. Fluctuation in the exchange rate can eventually lead to financial monetary vulnerability since it potentially affects the inflation rate. The inflation rate will push prices up and in turn, will weaken the purchasing power and ultimately reduce the quality of life. ${ }^{1}$ It is clear that exchange rate fluctuations have an impact on the economy and the lives of the wider community: just different degrees and impacts.

Monetary stability in a country is the main element in the establishment of a good economy that can support economic growth and equality for its people. Especially for a country whose economy is predominantly supported by the banking sector, it requires the role of the central bank that has the authority to maintain monetary stability.

${ }^{1}$ Prasetyantoko, A. (2008). Bencana Finansial, Stabilitas sebagai Barang Publik. Jakarta: Kompas, p. 12-16. 
Therefore, it is the duty of the state to form a central bank (namely Bank Indonesia/BI) whose task is to maintain monetary stability.

In order for BI to be able to carry out its activities, functions and duties, as stipulated in Law No. 23 of 1999 concerning BI, the minimum BI's capital is two trillion Rupiahs. This minimum capital is calculated based on the estimated cost required by BI to maintain monetary stability. In addition, there are also measures that can be taken to preserve the integrity of the minimum capital.

There is possibility of cost fluctuations because the monetary sector is a vulnerable area for movement and is contagious between regions and between sectors. There is also possibility that the expenditure are greater than the income which cause a capital deficiency. In such a situation, BI will use general reserves to deal with risks that may arise from the implementation of BI's duties and powers. ${ }^{2}$ When the general reserve cannot cover the shortage of capital, the partial or entire economic surplus of the current years can be used to settle the problem. ${ }^{3}$

Learning from the 1997/1998 financial crisis, in order to anticipate instability and strengthen the monetary sector, arrangements for closing BI capital shortages have changed, which in Article 63 Paragraph (3) of Law No. 23 of 1999 concerning Bank Indonesia in conjunction with Law No. 3 of 2004 stipulates that the Government with the approval of the DPR is obliged to cover the shortage of BI capital if BI is no longer able to overcome it.

Fulfilling the Government's obligation to meet BI's shortage of capital is placed as a fiscal risk in the APBN. Placement as a fiscal risk in the APBN is due to the fulfillment of these obligations only when there is a shortage of BI capital. So only a potential or risk. ${ }^{4}$ Fiscal risk provides fiscal pressure, which results in reduced policy space (fiscal flexibility) and affects the role of the budget as a development stimulus. Until now, the role of the APBN as the creator of the development stimulus is still the main role in line with the function of the State Budget stipulated in the 1945 Constitution, namely for the greater prosperity of the people. ${ }^{5}$

The budget items listed in the APBN must reflect the government's efforts to bring the Indonesian people to the conditions determined in accordance with the objectives of the establishment of the Republic of Indonesia. Determination of fiscal risk for reduced $\mathrm{BI}$ capital must have the right reasons so that the APBN function can still be realized.

Based on this background, the problems raised in this study are (1) why the Government is obliged to meet BI's lack of capital; (2) what is the mechanism for fulfilling the Government's obligations to meet BI's shortage of capital in line with the objectives of the APBN?

\footnotetext{
2 Article 1 number 11 and explanation of Article 62 Paragraph (1) of Law No. 23 of 1999 concerning Bank Indonesia.

${ }^{3}$ Law No. 23 of 1999 concerning Bank Indonesia junto Law No. 3 of 2004 about Amendment Law No. 23 of 1999 concerning Bank Indonesia.

4 "Fiscal risk is a source of financial stress that could face a government in the future." Hana Polackova Brixi and Allen Schick (eds.), Government at Risk, Contingent Liabilities and Fiscal Risk, A Copublication of the World Bank and Oxford University Press, 2002, p. 1.

${ }^{5}$ Article 23 Paragraph (1) of the Amendment of 1945 Constitution.
} 


\section{Method}

The research method used is a normative juridical research method with a statutory approach, an interdisciplinary approach (law, economics, and politics), and an analytical approach. This approach is used to refer to the nature of the law, which is comprehensive, all-inclusive, and systematic.

\section{Analysis and Results}

\subsection{Theoretical Framework}

Article 23 Paragraph (1) of the amendment to the 1945 Constitution stipulates "The State Revenue and Expenditure Budget as a form of state financial management is stipulated annually by law and implemented openly and responsibly for the greater prosperity of the people." This provision has a juridical meaning, namely (1) determining the state's means to achieve state objectives, namely through the budget plan and government work plan as stipulated in the APBN; (2) provide constitutional limits on the role and function of the State Budget to achieve the prosperity of the people in accordance with the objectives of the state as stated in the Preamble to the Constitution. This is in accordance with the function of budgeting, namely, as a tool that contains steps to achieve certain goals. As stated by Robert D. Lee, Jr. and Ronald W. Johnson as follows. "Public budgeting involves the selection of ends and the selection of means to reach those ends. Public budgeting systems are systems for making choices about ends and means." 6 For this reason, the APBN must reflect the real efforts and steps of the Government in realizing the achievement of the goals of the state. The benchmark of budgeting is not efficiency but the achievement of the goals of the state.

From a legal perspective, utility theory is a theory that puts benefit as the main goal of the law. The state as the holder of power must be able to form laws that embody the interests of society (interessenjurisprudenz) and are beneficial to people's lives. The regulation of the Government's obligation to meet BI's minimum capital shortage as a fiscal risk in the APBN must bring benefits to the people in accordance with legal objectives.

In a legal relationship, to have a legal relationship or a legally binding act, it can only be done by a legal subject as a bearer of legal rights and obligations and has the ability to act according to law. In Articles 1329 and 1654 of the Indonesian Civil Code, the legal subject can be a private person (natuurlijke persoon) and a legal entity (rechtpersoon).

In relation to the assets they own, legal entities are adhered to with the right to manage their assets in order to achieve their goals. As a juridical implication, all actions taken on such assets and their impact (risk) are the responsibility of the legal entity.

The state is a public legal entity,7 which can form other legal entities, both public and civil in nature. The juridical implications in the event that the state separates wealth to form other legal entities are:

(1) for the country are:

${ }^{6}$ Lee, R.D.Jr \& Ronald W. Johnson, R.W. (1978). Public Budgeting Systems, second edition (Baltimore: University Park Press, p. 1.

7 Burgerlijk Wetboek, Dutch 1992. Book II. 
a. the state no longer manages the assets that have been separated,

b. the state is not responsible for anything that happens to said-assets and cannot be held responsible for the management carried out on said assets;

(2) for legal entities established are:

a. assets received become assets of a legal entity,

b. legal entities have the authority to make arrangements in order to manage assets received for use in order to achieve the objectives of the legal entity,

c. legal entities are responsible for all legal consequences (risks) that occur on the assets they manage.

BI is a legal entity established by the state. Based on the theory of transformation, as long as the actions were taken by a legal subject (in the form of separation and/or delivery) cause the transfer of finance to another legal subject, there has been a transfer and transformation of the legal status of finance, ${ }^{8}$ because as previously stated, every legal subject is the bearer of rights and obligations. The relationship with the giver (the original legal subject) has been terminated, and all rights and obligations on the finance, in this case, management and responsibility, are transferred to the recipient (legal subject) of the finance. Furthermore, the recipient has the right to make arrangements and manage autonomously according to their interests. From a juridical perspective, rights are always followed by obligations, as for the obligation of the legal subject of the recipient to carry out management according to their interests and to be responsible for the management. Therefore, BI has the authority to manage the separated state assets deposited by the State to become BI's initial capital and is responsible for all risks for the management of such assets.

\subsection{Determination of Government Obligations to Meet BI's Capital Shortages}

As previously stated, the regulation of the government's obligation to meet BI's shortage of capital as a result of the implementation of BI's duties and powers began in Law No. 23 of 1999. In the previous regulation, there was never a mention of the Government's liability for BI's lack of capital. The role of the state over BI is only manifested in the capital that is first given in the amount stipulated in the law, and thereafter the state can make additional capital, which is due to the development of financing needs in the implementation of BI duties demanding additional capital according to economic developments (inflation, and others) (Article 4 of Law No. 13 of 1968 concerning the Central Bank). Unlike the case with the norms listed in Article 62 Paragraph (3) of Law No. 23 of 1999, which explicitly regulates "In carrying out the duties and powers of BI resulting in BI's capital is less than two trillion, the Government (with the approval of the DPR) is obligated to cover the shortfall (difference). State responsibility is situational (contingent), which only occurs when the initial capital is reduced. In addition, it is also stipulated that prior to submitting a request to the Government to cover the difference in capital shortages, BI is obligated to cover the shortage of capital by using the BI surplus for the current year, partially or completely.

\footnotetext{
8 Atmadja, A. P. (2005). Keuangan Publik dalam Perspektif Hukum. Depok: Badan Penerbit Fakultas Hukum, Universitas Indonesia, p. 125.
} 
Based on a legal perspective and based on the theory of legal entities, to review the value of the benefits of determining the Government's obligation to meet BI's shortage of capital, there are two elements that need to be analyzed:

First, it is seen from the financial legal status of capital, from the perspective of a legal entity. The relationship that occurs between the state and BI is as follows. The state as the original legal entity (forming) and BI as the legal entity (which was formed). Based on the BI Law, BI is designated as a legal entity (Law No. 23 of 1999 concerning Bank Indonesia). The BI Law is a formal legal form of BI formation. The state as the founder of BI provides an amount of money originating from assets separated as BI capital. In accordance with the doctrine of a legal entity, each legal entity has assets separate from its founder, and the legal entity has the right to manage such assets in order to carry out activities to achieve the objectives of the legal entity. As a juridical implication of the rights, they have to manage the assets, and the legal entity is also responsible for all the impacts and risks that occur in the management of their assets. In accordance with the institutional legal status of BI as a legal entity, the legal concepts that apply to legal entities also apply to BI. Therefore, legally speaking, money originating from state finances deposited by the state with BI changes its legal status to BI finance. Changes in the legal status of finance, then the right to manage the capital rests with BI. In line with the right to financial management, there is also an obligation to be responsible for its management and management, including responsibility for risk burdens. Therefore, BI has responsibility for the management of capital, including responsibility for the risk of capital depletion. The adequacy of BI's lack of capital is the burden and responsibility of BI. BI must maximize its efforts to return capital to its original state. Meanwhile, BI's responsibility is achieved by using a portion or all of the current year's surplus to cover the capital deficit.

Second, the relationship that occurs within the framework of the state as a legal entity and $\mathrm{BI}$ as an implementing organ. In the perspective of a legal entity, the state is a public legal entity. For the implementation of state duties in the monetary sector, the state is represented by BI. This is emphasized in the BI Law, that BI is an organ that gets the power from the state as the public authority to carry out duties and authorities in the monetary and banking sector (customer guarantee and banking restructuring). The BI Law is a legal form of granting authority from the state to BI to carry out state tasks. Thus, the relationship between the state and BI from the perspective of a legal entity is the state as a legal entity and BI as the implementing organ. Therefore, such a position, related to juridical accountability has the following implications.

(1) As long as BI's actions are carried out based on the authority and duties assigned to it by law, the consequences (risks) of such actions will become the burden (responsibility) of the State, as the giver of authority (public legal entity).

(2) If the actions taken by BI (as executor of a state public legal entity) are outside the authority and duties given by the law, then the consequences (risks) of such actions will become the burden (responsibility) of BI.

Using the perspective of a legal entity, especially with regard to capital, juridically, BI's lack of capital will only become a burden to the state as long as the shortage of capital is caused by BI's actions in the framework of carrying out its duties and powers given by law. If the shortage of BI capital is caused by actions taken by BI outside the corridors of duties and authorities given by law, then closing such capital shortages must become the responsibility of BI. The tiered pattern of responsibility places the state as the final responsibility. 
Referring to the above analysis, which is based on the legal entity doctrine, it is obtained an illustration that the fulfillment obligation of BI capital shortage is tiered, namely:

(1) At the first level, BI is fully responsible for maximizing efforts to meet its lack of capital;

(2) Furthermore, if BI fails to cover its shortage of capital, the State shall address it as a fiscal risk.

The tiered pattern of accountability implies:

a. minimize the funds issued by the government;

b. minimize fiscal pressure caused by the fiscal risk of closing BI capital shortages.

Therefore, the determination of fiscal risk for BI capital shortage should be interpreted as a manifestation of the role and obligations of the state:

a. in maintaining monetary stability; and

b. providing protection and increase the value of the benefit to the people.

Based on an economic perspective, the analysis of the value of benefits determines the state's obligation to meet BI's shortage of capital is as follows. First, the state has the responsibility for the state economy, because the economic sector is in direct contact with the lives of the people and the people's welfare, so it is the state's obligation to maintain economic stability and economic growth so that people's welfare can be achieved. One of the ways to achieve economic stability and economic growth is by maintaining monetary stability. Monetary stability can be achieved, among others, if the existence of public authorities that have duties and authorities in this field is maintained. For this reason, the state must be responsible for maintaining the existence and continuity of BI's duties and authorities through maintaining adequate capital. Through this role, the state upholds its responsibility in protecting the people from adversity as mandated in the Preamble of the 1945 Constitution. Second, while the state suffers from a shortage of BI capital, the state actually prevents a more severe negative impact on the real sector, especially the people. As illustrated in the previous description, the result of monetary instability has a profound negative impact on the country's economy in general and the lives of the people in particular and also requires a lot of funds and a long time to restore the situation. Thus, the selection of a scheme to determine the state's obligation to meet BI's capital as a controversial fiscal risk can actually ease the burden on the state compared to the state having to bear the burden of restoring monetary and financial sector instability due to BI's powerlessness (if BI's capital is insufficient and it has to be liquidated). Based on an economic perspective, the maximum benefit value for the people can be achieved by determining the fiscal risk of reducing BI capital.

Based on a political perspective, the value of the benefits of determining the Government's obligation to meet BI's shortage of capital can be analyzed as follows. In a country that is based on democratic principles, people's trust is the main asset and becomes important to maintain people's trust. A government that is not credible has an impact on government, economic and social shocks. Learning from the experience of handling the 1998 economic crisis, the monetary crisis developed into an economic, political and social crisis that actually gave suffering to the people. For this reason, it is 
important for the Government to maintain its credibility. Determination of the Government's obligation to meet BI's shortage of capital has implications for the sustainability of BI's function as the central bank, namely maintaining monetary stability. This refers to the importance of monetary stability to the country's economy, as stated by Lipjhart below.

"The most important task of central banks is the making of monetary policy - that is the regulation of interest rates and the supply of money. Monetary policy has a direct effect on price stability and the control of inflation, and it indirectly, but also very strongly, affecting levels of unemployment, economic growth, and fluctuations in the business cycle." 9

From this statement, it is illustrated that the monetary sector plays a very important role in maintaining economic stability and even the real sector. With controlled monetary conditions, the economy could continue to grow and develop so as to lead to an increase in people's welfare. These conditions will have implications for increasing people's trust in the credibility of the Government.

\subsubsection{Mechanisms for Fulfilling Government Obligations to Meet BI's Lack of Capital in Accordance with the Purpose of the State Budget}

The fourth paragraph of the Preamble of the 1945 Constitution ${ }^{10}$ contains the objectives of the Indonesian state, namely: "To protect the entire Indonesian nation and all the blood of Indonesia and to promote public welfare, protect all spilled Indonesian blood, educate the nation's life and participate in implementing world order based on independence, eternal peace, and social justice. " To achieve this goal of a state, the Government is mandated to organize a government through various programs and activities. As an embodiment, each year an activity plan and budget are made in the form of an APBN, as regulated in Article 23 Paragraph (1) of the amendment to the 1945 Constitution, which regulates "The State Revenue and Expenditure Budget as a form of state financial management is stipulated annually by law and implemented openly and responsibly for the greatest prosperity of the people." This provision has a juridical meaning, namely (1) determining the state's means to achieve state objectives, namely through the budget plan and government work plan as stipulated in the APBN; (2) provide constitutional limits on the role and function of the State Budget to achieve the prosperity of the people in accordance with the objectives of the state as stated in the Preamble to the Constitution.

APBN contains budget plans and work plans that bring people closer to the goals of the state. This is in accordance with the budget function as stated by Robert D. Lee, Jr. and Ronald W. Johnson as follows. "Public budgeting involves the selection of ends and the selection of means to reach those ends. Public budgeting systems are systems for making choices about ends and means."11 For this reason, the Government's budget plan and work plan listed in the APBN must reflect the Government's concrete efforts and steps in achieving the goals of the state. At least the government must ensure the fulfillment of the people's basic needs by allocating funds in the state budget.

\footnotetext{
9 Lipjhart, A. (1999). Pattern of Democracy: Government Forms and Performance in Thirty-Six Countries. New Haven and London: Yale University Press, p. 233-234.

${ }^{10}$ Indonesian 1945 Constitution, LN No. 75 Year 1959, BN No. 69 Year 1959.

${ }^{11}$ Lee, R.D.Jr \& Ronald W. Johnson, R.W. (1978). Public Budgeting Systems, second edition Baltimore: University Park Press, p. 1.
} 
Gruber further states the following.

"The government's role in the economy raises the fundamental questions addressed by the branch of economics known as public finance. The goal of public finance is to understand the proper role of the government in the economy. On the expenditures side of public finance, we ask: what kind of services should the government provide, if any? Why is the government the primary provider of goods and services such as highways, education, and unemployment insurance, while the provision of goods and services such as clothing, entertainment, and fire insurance is generally left to the private sector? On the revenue side of public finance, we ask: How should the govern-merit raise the money confirmed its expenditures? What kind of soft taxes should be levied. Who should pay them, and what effects do they have on the functioning of the economy?"12

This can be done by the government through policies and regulations that are oriented towards the welfare of the people, in various ways, especially by promoting efficiency, reducing poverty, achieving equality of opportunities (non-discrimination), social inclusion, political and economic stability as well as economic, political, administrative and economic decentralization. fiscal sustainability. ${ }^{13}$

Fiscal sustainability is the fiscal capacity to implement various government policies and programs while maintaining macroeconomic stability. ${ }^{14}$ The global economy is currently carrying an open economy that is prone to shocks. This creates budgetary uncertainty, which will put fiscal pressure on because of the potential to burden the budget. This is categorized as fiscal risk, as suggested by Brixi and Schick, who define fiscal risk as "a source of financial stress that could face a government in the future."15

Experience shows budget pressures affect budget health. ${ }^{16}$ Therefore, any pressure arising from both direct and contingent liabilities must be included in the budget.

Juridically, the fiscal risk is a potential budget burden that becomes the obligation of the state if the conditions in that fiscal risk are met. The most extreme implication is a disruption in the delivery of public services. Therefore, the State is required to act prudently and carefully in determining fiscal risks to avoid fiscal burdens that are not in accordance with budgeting objectives, which will result in fiscal pressure and disrupt fiscal sustainability, which will result in disruption of the implementation of the country's main obligations to achieve state objectives.

Article 62 Paragraph (3) Law No. 23 of 1999 concerning Bank Indonesia stipulates that if there is a lack of capital as a result of the implementation of BI's duties and powers, it becomes the obligation of the Government with the approval of the DPR to cover the

12 Gruber (2005) in Machfud Sidik, "Analisis Peranan BUMN dalam Pembangunan, Keuangan Negara dan Kinerjanya sebagai Korporasi," in Aktualisasi Hukum Keuangan Publik, Yuli Indrawati, ed., (Bandung: Mujahid Press, 2014), p. 276-277.

13 J.B. Sumarlin in Ibid., p. 279.

14 Ibid.

15 "Fiscal risk is a source of financial stress that could face a government in the future." Hana Polackova Brixi and Allen Schick (eds.), Government at Risk, Contingent Liabilities and Fiscal Risk, A Copublication of the World Bank and Oxford University Press, 2002, p. 1.

16 The sizeable costs of crisis management in countries that experienced a crisis in 1997/1998 put a great deal of pressure on the budget where the burden on the budget increased, thus disrupting the ability of the budget to finance its expenditures. In fact, several countries have had to reschedule their debt payments, reducing various programs to achieve budget balance. 
deficiency. These norms are the legal basis for the inclusion of these Government obligations as fiscal risks in the APBN. This Government obligation is a fiscal risk because the obligation is only in the form of a potential that will be born if three conditions are met, namely first, a lack of capital caused by the implementation of BI duties and authorities; second, there is a certain amount that is used as a benchmark for lack of capital; and third, there is DPR approval for these obligations.

Inclusion of fiscal risk in the APBN does not mean that approval has been given by the DPR, but only to illustrate potential fiscal risks. When the required condition occurs, juridically, the potential fiscal risk will turn into a liability.

Referring to the BI Law, there are several steps that must be passed in terms of fulfilling the shortage of BI capital by the Government, namely as follows. ${ }^{17}$

1. after it is discovered that there is a shortage of capital (based on the annual report), BI must make maximum efforts to cover the deficiency by using the BI surplus for the current year, partially or completely;

2. in the event that this is not able to overcome the minimum capital shortage, BI will submit a request to the Government to cover the difference in capital shortages. There is a lack of capital as evidenced by the BI annual report, which has been audited by the Supreme Audit Agency (BPK);

3. based on the said request and the results of the BPK audit on the BI annual report, the Government shall conduct an examination of the causes of the lack of capital;

4. in the event that the shortage of capital is caused by factors beyond BI's control, the Government shall forward the request for capital closure to the DPR through the submission of the State Budget Bill by allocating the capital deficiency in the financing budget item (in the form of government bonds);

5. in the event that the DPR considers that the closure of BI's shortage of capital is indeed beneficial for the interests of BI's institutional sustainability, the DPR may give its approval through approval of the RUU APBN;

6. The government's obligation to cover BI's minimum capital shortage is carried out by issuing government bonds.

Such coping mechanisms can be viewed from an economic, legal and political perspective as follows.

a. funds issued by the government have been minimized because efforts to overcome capital shortages have been made maximally by BI. (economic perspective);

b. there are two judgments, namely testing the reasons for the occurrence of BI capital shortages, namely the deficiency occurring in the framework of implementing BI duties (legal perspective); and testing the benefits of providing funds for the interests of the people (political perspective)

c. it can be ascertained that fiscal pressures resulting from the occurrence of fiscal risks for closing BI capital shortages can be minimized; so that fiscal sustainability is maintained; monetary stability is maintained; the economy

${ }^{17}$ Law No. 3 of 2004 concerning Amendment Law No. 23 of 1999 concerning Bank Indonesia, Article 62 paragraph (3). 
remains under control; the negative impact on the real sector can be minimized; and basic services of the people can still be fulfilled by the state.

Accordingly, the government's obligation to meet BI's shortfall in the capital is contingent, tiered and final.

\section{Conclusion}

Based on the results of the above analysis, it can be concluded that:

1. Determination of the Government's obligation to meet the shortage of BI capital is intended to maintain the existence of BI institutions and the continuity of BI's duties in maintaining monetary stability, so as to provide protection to the public against excess monetary instability that can disrupt people's lives and reduce the level of social welfare. This is in line with the state's duty to provide protection for the community and improve the welfare of the community.

2. The mechanism for fulfilling the Government's obligations to meet BI's shortage of capital in line with the objectives of the APBN is to place this obligation as a fiscal risk (contingent in nature) in the APBN. This determination has the meaning of recognizing a potential fiscal burden. In the event of a lack of capital, the next step to be taken is an independent settlement by BI. If the efforts made by BI are still unsuccessful, then BI will submit a request to the Government for approval by the DPR. The government will conduct an assessment from a legal perspective, while the DPR will conduct an assessment from a political perspective. With such a mechanism, the function of the State Budget as stipulated in the 1945 Constitution, namely for the greatest possible prosperity of the people, is still fulfilled.

To maintain fiscal sustainability, the authors suggest, for every risk set out in the State Budget, be it a direct obligation or a contingent obligation, a reserve fund is prepared. For the State, the reserve fund will demonstrate the readiness of the Government to deal with risks that occur and provide services for the basic needs of the community, thereby increasing the credibility of the Government. For government administrators, the reserve fund will guarantee certainty in the form of (a) the continuity of the implementation of programs and activities; and (b) the absence of a significant reduction in funds in other budget items, which resulted in delays in programs and activities. For the community, reserve funds mean (a) the basic needs of the community are still available; and (b) the impact of monetary instability will not affect people's lives. The provision of reserve funds for fiscal risk is also in accordance with the modern budgeting concept, which always provides funds to deal with risks so that fiscal sustainability can be maintained.

\section{References}

\section{Books}

Adiningsih, S. (2012). Koordinasi dan Interaksi Kebijakan Fiskal-Moneter: Tantangan ke Depan. Yogyakarta: Kanisius.

Atmadja, A. P. (2005). Keuangan Publik dalam Perspektif Hukum. Depok: Badan Penerbit Fakultas Hukum, Universitas Indonesia.

Boediono. (2016). Ekonomi Indonesia dalam Lintasan Sejarah. Jakarta: Mizan. 
Lee, R.D. Jr. \& Johnson, R. D. (1978). Public Budgeting Systems. Baltimore: University Park Press.

Lipjhart, A. (1999). Pattern of Democracy: Government Forms and Performance in Thirty-Six Countries. New Haven and London: Yale University Press.

Prasetyantoko, A. (2008). Bencana Finansial, Stabilitas sebagai Barang Publik. Jakarta: Kompas.

Savi, T. (2011). Some Approaches for Assessing The Sustainability of Public Finances. Aalto University School of Economics.

Schick, H. P. (2002). Government at Risk, Contingent Liabilities and Fiscal Risk. The World Bank and Oxford University Press.

Indrawati, Y. (2014). Aktualisasi Hukum Keuangan Publik. Bandung: Mujahid.

\section{Journals and Articles}

C., J. I. (2013). From the Editor: The Politics of Inequality in the Face of Financial Crisis. Perspectives on Politics, 11(1), 1-7. Retrieved February 18, 2017, from http://www.jstor.org/stable/43280685

Chappe, R., Nell, E., \& Semmler, W. (2013). The Financial Crisis of 2008 as Cognitive Failure: an Overview of Risk Over Uncertainty. Berkeley Journal of Sociology, 57, 9-39.

Desmod, M. (2013). Is Democratic Regulation of High Finance Possible? The Annuals of the American Academy of Political and Social Science, 649, 180-184. Retrieved February 18, 2017, from http://www.jstor.org/stable/23479129

Doraisami, A. (2013). Fiscal Policy Challenges in Developing Countries: The Indonesian Experience in Responding to the Global Financial Crisis. Journal of Southeast Asian Economics, 30(3), 322-333. Retrieved February 18, 2017, from http://www.jstor.org/stable/43264688

Greespan, A. (2013). Never Saw it Coming: Why the Financial Crisis Took Economists by Surprise. Foreign Affairs, 92(6), 88-96. Retrieved February 18, 2017, from http:/ / www.jstor.org/stable/23527015

Hakim, L. (2011). Rekonstruksi Peran Negara dalam Penyelenggaraan Negara Secara Konstitusional. Jurnal Masalah-Masalah Hukum, 40(2), 246-255. Retrieved February 18, 2017

Lee, H. O. (2013). Welfare States and the Redistribution of Happiness. Social Forces, 92(2), 789-814. Retrieved February 18, 2017, from http://www.jstor/stable/ 43287812

Litonjua, M. (2013). State vs Market: What Kind of Capitalism? International Review of Modern Sociology, 39(1), 53-87. Retrieved February 18, 2017, from http://www.jstor.org/stable/43496479

McNamara, D. W. (2013). International Political Economy, Global Financial Orders and the 2008 Financial Crisis. Perspectives on Politics, 11(1), 155-166. Retrieved February 18, 2017, from http://www.jstor.org/stable/43280694 
Nizar, M. A. (2011). Siklikalitas Kebijakan Fiskal di Indonesia. Jurnal Keuangan dan Moneter, 14(1), 52-82.

Prasetyia, F. (2011, Oktober). Rekonstruksi Sistem Fiskal Nasional dalam Bingkai Konstitusi. Journal of Indonesian Applied Economics, 5(2), 141-156.

Prasetyo, K. F. (2012, September). Politik Hukum di Bidang Ekonomi dan Pelembagaan Konsepsi Welfare State di dalam UUD 1945. Jurnal Konstitusi, 9(3), 495-514.

Rosenhek, Z. (2013, September). Diagnosing and Explaining the Global Financial Crisis: Central Banks, Epistemic Authority and Sense Making. International Journal of Politics, Culture, and Society, 26(3), 255-272. Retrieved February 18, 2017, from http://www.jstor.org/stable/24713370

S., R. M. (2015). Analisis Keberlanjutan Fiskal Indonesia Tahun 2000-2012. Bina Ekonomi, 19(1), 1-14. 